When Bad Things Happen to Rich People 



\title{
When Bad Things Happen to Rich People
}

\author{
A Novel
}

Ian Morris

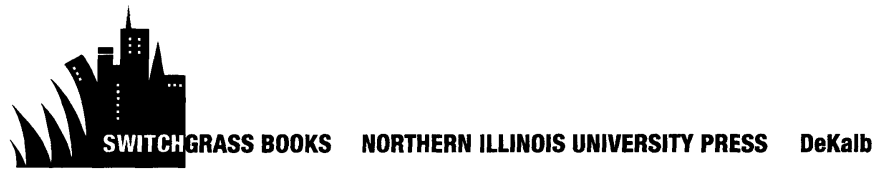


(C) 2014 by Switchgrass Books, an imprint of Northern Illinois University Press

Published by the Northern Illinois University Press,

DeKalb, Illinois 60115

\section{All Rights Reserved}

Design by Shaun Allshouse

This is a work of fiction. All characters are products of the author's imagination, and any resemblance to persons living or dead is entirely coincidental.

Library of Congress Cataloging in Publication Data Morris, Ian, 1961-

When bad things happen to rich people : a novel / Ian Morris.

pages $\mathrm{cm}$

ISBN 978-0-87580-709-6 (pbk : alk. paper)-

ISBN 978-1-60909-167-5 (e-book)

1. College teachers-Fiction. 2. Advice columnists-Fiction. 3. Publishers and publishing-Fiction. 4. Ghostwriting-Fiction. 5. Chicago (Ill.)Social life and customs-20th century-Fiction. I. Title.

PS3613.O7724W44 2014

813'.6--dc23

2014007746 
For Zelda 
